\title{
Differences in Mathematical Communication Skills Using Draft Pocket Books and Domino-Based Cards PMR
}

\author{
Tsuwaibatul Aslamiyah Lubis \\ Graduation Mathematics Education \\ Post \\ Universitas Negeri Medan \\ Indonesia \\ aslamiyahlubis20@gmail.com
}

\author{
Asrin Lubis \\ Mathematics Education \\ Universitas Negeri Medan \\ Indonesia
}

\author{
Pargaulan Siagian \\ Mathematics Education \\ Universitas Negeri Medan \\ Indonesia
}

\begin{abstract}
This study aims to find out: Differences in ability Communication skills that use pocket pocket machinesand those using PMR-based This study is a quasi-experimental study. The population of this study were students of class VII 239 TA 2017/2018. Sample selection is done by simple random samplingby randomizing the class. The instrument used consisted of: communication skills test and problem solving ability with student activity sheets. Data in this study were analyzed using descriptive statistical analysis and inferential analysis. Inferential analysis of data is carried out using the t-test. The results showed that there were differences in communication ability using a draftpocketbook and a PMR-based domino card. It is based on ttest analysis results for the model obtained $t_{\text {hitung }} 3.006$ and $t_{t a b e l} 2,056 \mathrm{sig}=0.004$. where is the value of this sig that is Criteria 0.05.
\end{abstract}

Keywords-Communication Ability; Book Draft Pocket; dominoes; Bebasis PMR

\section{INTRODUCTION}

Researchers still conduct research observations of many teachers who embrace the paradigm of transfer of knowledgeMathematics is a universal science that underlies the development of modern technology, has an important role in various disciplines of advancing human thinking power. Therefore mathematics is very important to learn, as expressed by Cornelius (Aburrahman, 2003). Five reasons for the need to learn mathematics include: 1) a clear and logical means of thinking; 2) means to solve problems in everyday life; 3) means of recognizing relationship patterns and generalizing experiences; 4) means to develop creativity; and 5) means to increase awareness of cultural development [1].

Understanding Communication is a process of formation, delivery, acceptance and processing of messages that occur within a person and or between two or more with a specific purpose. As Lasswell (Daryanto, 2013) says that communication is something related to "who said or expressed what, with what communication channels, to whom and with what impact or results achieved. communication is the process of delivering information or messages among several people and aims to invite people to understand what we convey in achieving the goal [2]. According to Mohammda Zain in Milman (Yusdi, 2011) means that Ability is ability, ability, strength we strive with ourselves. Communication in mathematics is related to students' abilities and skills in communicating. Evaluation standards for measuring these abilities are (1) Expressing mathematical ideas by speaking, writing demonstrations, and describing them in visual form, (2) understanding interpreting, and assessing mathematical ideas presented in writing, oral or visual forms, (3) using vocabulary word / language, mathematical notation and structure to express ideas, describe relationships, and model making [3]. This means mathematical communication is the integration between understandingthematically (and doingto knowing and doing mathematics). Meanwhile, mathematical communication as a verbal explanation of mathematical reasoning measured through three dimensions, namely truth (correctness), fluency in providing various correct answers to mathematical representations, in formal form, visual, algebraic equations, and diagrams.

Mathematical communication skills can occur when students learn in groups, when students explain algorithms to solve an equation, when students present a unique way to solve problems, when students construct and explain a physical representation of real-world phenomena, or when students provide a construct about images - geometry drawings.

Understanding Problem Solving Problem solving is part of the mathematics curriculum which is very important because in the learning process as well as the completion of the students it is possible to gain experience using the knowledge and skills already possessed to be applied to problem solving. (Suryadi, 2000) states that problem solving ability is a very important activity in solving students trying to answer 
questions or solve problems, they are also motivated to work hard. Problem solving ability is the process of applying knowledge that has been obtained previously into new situations that are not yet known, learning mathematics [4].

Understanding Realistic Mathematics learning is a concept or procedure used in discussing a lesson material. A realistic mathematical approach (PMR) is the delivery of a mathematical topic that starts from things that are real or have been experienced by students before. Realistic mathematics learning is basically utilizing the reality and environment that is understood by students to expedite the learning process of mathematics so as to achieve the goals of mathematics education better than before

(Asrin Lubis, 2006) Realistic Mathematics (PMR) is an approach to learning mathematics that utilizes objects or environment as teaching aids as a material utilizing the reality that exists around the social environment of students so that learning mathematics can be more easily understood by students [5]. And according to Edi Shahputra (2013), that in general a realistic mathematical approach consists of five characters, namely: (1) the use of "real context" (2) the use of "models" (3) the linkages in and between mathematical topics; (4) Use of interactive methods and (5) appreciate variations in student answers and contributions [7].

The Pocket Book draft with pictures and interesting appearance can influence student learning outcomes. In accordance with the statement of James W. Brown, et al which states that from some of Edmund Faison's research results on the use of images shows that to obtain maximum learning results, the pictures must be closely related tolearning material

Domino cardis a kind of game that can be done on the floor or table using pieces wood or paper as much as 28 pieces according to Muh Taufiqurrohma (2012) "Domino card games are two square numbers including pairing one-to-one activities in general a two-square number game device consisting of 28 cards, but the number of cards can be changed according to need. Materials used as thick paper bases such as cards or manila "[8]

Dimino cards packaged in the form of educational games are expected to make the learning process more interesting and students actively involved in learning activities. A domino card is a card made of thick rectangular paper with certain material written on it. And according to Heksanti (2012) "The permanent media of dominoes is an intermediary used in games using paper which is formed at a certain size which consists of a collection of numbers that have meaning to achieve learning objectives" so that the media of domino card games makes it easy for students to solve mathematical problems and provide understanding of mathematical concepts in play so that students do not feel bored and bored [9].

\section{METHOD}

This study aims to find out the differences in communication skills and problem solving abilities taught by using draft pocket book and PMR-based domino cards.
Research Design The design of this study was in the form of a non-equivalent control group design

. TABLE 1. Research Design

\begin{tabular}{|c|c|c|}
\hline Group & Treatment & Postest \\
\hline Experiment 1 & $\mathrm{P}_{1}$ & $\mathrm{O}$ \\
\hline Experiment 2 & $\mathrm{P}_{2}$ & $\mathrm{O}$ \\
\hline
\end{tabular}

Where:

Experiment-1: Class Using a PMRbased domino card

Experiment-2: Class using a draft pocket bookbased on PMR

$\mathrm{P}_{1}$ : Treatment using dominoes based on PMR

$\mathrm{P}_{2}$ : Treatment using a draft pocket bookbased on PMR

$\mathrm{O}$ : Posttest in experimental class-1, experiment-2

\section{A. Research Instrument}

This study used two types of instruments, namely test instruments. Test instruments in the form of communication skills tests and problem solving skills

\section{B. Instrument Testing}

Before the research instrument was used, the contents of all test devices were validated and analyzed by three lecturers and two teachers of mathematics subjects. Content validity is determined based on the suitability between the question grid and the item.

After expert validation of the research instrument, then the instrument with sufficient content validity was tried out to students who were outside the research sample. This is done to see the validity, reliability.

\section{Inferential Statistical}

Analysis Analysis of the parameters of the use used to see the difference in the ability of the communication capability of the experiment- 1 class, experiment- 2 class.

\begin{tabular}{|c|c|c|c|c|c|c|}
\hline \multicolumn{1}{|c|}{ TABLE 2. Communication capability } \\
\hline $\begin{array}{c}\text { Commu } \\
\text { nication } \\
\text { ability }\end{array}$ & Group & $\begin{array}{c}\text { Num } \\
\text { ber } \\
\text { of }\end{array}$ & $\begin{array}{c}\text { Minim } \\
\text { um }\end{array}$ & $\begin{array}{c}\text { Maximu } \\
\mathrm{m}\end{array}$ & $\begin{array}{c}\text { Mean } \\
\text { Stude } \\
\text { nts }\end{array}$ & $\begin{array}{c}\text { Stand } \\
\text { ard } \\
\text { Devia } \\
\text { tion }\end{array}$ \\
\cline { 2 - 8 } & $\begin{array}{c}\text { Experime } \\
\text { nt-1 }\end{array}$ & 28 & 22.00 & 54.00 & $\begin{array}{c}40.60 \\
71\end{array}$ & $\begin{array}{c}8.434 \\
23\end{array}$ \\
\cline { 2 - 8 } & $\begin{array}{c}\text { Experime } \\
\text { nt-2 }\end{array}$ & 28 & 27.00 & 47.00 & $\begin{array}{c}34.78 \\
57\end{array}$ & $\begin{array}{c}5.820 \\
51\end{array}$ \\
\hline
\end{tabular}

\section{RESULT AND DISCUSSIONS}

To answer the research questions raised in the introduction, an analysis and interpreatation of results data is needed research. The analysis in question is to find out the differences in communication ability and students' problem solving ability in fraction material, the experimental-1 class is taught using a domino based on PMR and experiment- 2 which is taught by 
using pocket pocket book. a PMR-based-soal communication skills and students' mathematical problem solving abilities.

\section{A. Research Results The}

Data analyzed were the results of the post test. communication skills, and students' mathematical problem solving skills. Post test results of communication skills and students' problem solving abilities in mathematics learning are taught using PMR-based dominoes and students who are taught using draft pocket booksPMR-based. followed by 28 students in the experimental class 1 and 28 students in the experimental class 2 .

\section{B. Description of Research Results Mathematical Communication Ability and Students' Mathematical Problem Solving Ability}

After calculating the post test results of mathematical communication skills and problem solving abilities in both experimental class 1 and the experimental class 2 can be seen in the attachment. The conclusion of the description of the results of the minimum, maximum, average, mean and standard deviation values as follows.

Based on the above table it can be seen that the minimum in experiment-1 22.00 and in experiment-2 27.00 with the maximum on experiment-1 54.00 and on experiment-2 47.00 From the summary of the above communication skills can be seen that in experiment-1 and experiment-2 there are differences significant between communication skills using the draft pocket book and domino cards.

TABLE 3 . Average of Mathematical Communication Ability Experiment-1 Siswa kelas and Experiment-2

\begin{tabular}{|lc|r|r|r|c|}
\hline & The group & $\mathrm{N}$ & Mean & $\begin{array}{c}\text { Std. } \\
\text { Deviation }\end{array}$ & $\begin{array}{c}\text { Std. Error } \\
\text { Mean }\end{array}$ \\
\hline $\begin{array}{c}\text { Experiment 1 } \\
\text { and }\end{array}$ & Experiment-1 & 28 & 40.607 & 8.43423 & 1.59392 \\
$\begin{array}{c}\text { Experiment 2 } \\
\text { Experiment-2 }\end{array}$ & 28 & $\begin{array}{r}34.785 \\
7\end{array}$ & 5.82051 & 1.09997 \\
\hline
\end{tabular}

Based on the above table it can be seen that experiment-1 with mean 40.6071 and experiment-2 34.7857 with standard deviation in ekpseriment-1 class 8.43423 and in ekpsreimen-2 class 5.82501 with a standard error of 1.59392 at experiment-1 and in experiment-2 1.09997.

TABLE 4 Analyst Students' Mathematical Communication Ability With t-

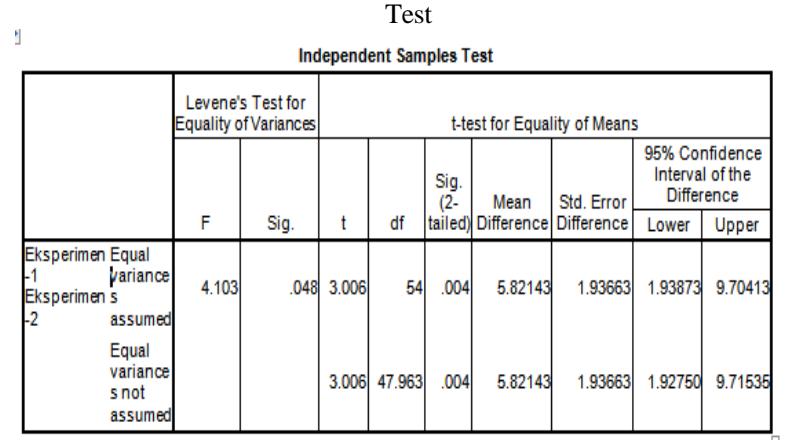

Based on the table 4 it can be seen that with table f 4.130 with significant 0.048 with t table on experiment-1 3,006 on experiment-2 3,006 with standard error 1,93663.

Hypotsis research 1 :

$H_{0}$ : Communication Ability using PMR-based dominoes.

$H_{a}$ : Communication Ability using the PMR-based Pocket Book Draft.

Hypothesis Statistics

$H_{0} x \mu_{1} \leq \mu_{2}$

$H_{\Omega^{x}} \mu_{1}>\mu_{2}$

Where:

$\mu_{I}$ : Communication Ability using cards. domino based on PMR

$\mu_{2}$ : Communication capability problems using the Draft pocket book based on PMR.

Testing Criteria are.

f sig $<0,05$ rejected $H_{0}$ or $t_{\text {hitung }} \geqslant t_{\text {tabel }}$ then $H_{0}$ rejected if the value sig $\geq 0,05$, then $H_{0}$ is received or the value of $t_{\text {hitung }}>t_{\text {tabel }}$ then Based on table 4.11 above is obtained the value of $t_{\text {hitung }} 3,006$ an $t_{\text {tabel }} \operatorname{sig}=0.004$ where this sig value is 0.05 , so there is a significant difference between communication skills using PMR-based dominoes and students taught using the draft pocket book.

\section{CONCLUSIONS}

Based on the results of the implementation and analysis of research data conducted on MTS students of class VII Pesantren Mawaridussalam Medan in 2017/2018 academic year, the results showed that there were significant differences in students' mathematical communication skills taught using dominoesthan students taught using ratherdraft pocked books. The details of the conclusions are as follows.

1. Mathematical Communication Ability of students taught using dominoes based on PMR is higher than students taught using draft pocked books PMR-based.

2. Mathematical Problem Solving Ability students taught using domino cards based on PMR are higher than students taught using draft pocked books PMR-based

3. Analysis of students' answers to errors taught using PMR-based dominoes is higher than students taught using draft pocked books PMR-based.

4. Analysis of students' answers to errors taught by using dominoes based on PMR is higher than students taught using draft pocked books PMR-based.

\section{ACKNOWLEDGMENT}

On this occasion the authors express their deepest gratitude to the beloved Buya and Ummi (Buya Drs. Akhiruddin Lubis and Ummi Dra. HJ Mariana M, S.PdI), Abang and Adik (Abang M. Akmar Yusfi Lubis Ssi Adik Halimatussakdiyah Lubis MKM, M. Abduh Lubis Mag, Nur Ahmad Fadhil Lubis and Nur Asiah amin Lubis) and all their beloved families who always prayed for, gave full and motivating support in completing this paper. 


\section{REFERENCES}

[1] Mulyono Abdurahman, Education For children learning difficulties, Jakarta: Rineka Cipta, 2003, h 253

[2] Daryanto, 2013 Effective Learning Innovation. Bandung YrmaWidya

[3] MillmanYusdi. 2011. Understanding of ability.diakes 11 November 2014.

[4] Suryadi K., 2000, Decision Support System, PT. Rosdakarya, Jakarta

[5] AsrinLubis, Realistic Mathematics Learning for Three Dimension Topics in class XHigh SchoolNeeri 2 Medanin 2006/2007. Accessed from (httpJurnal online.isjd.pdii.lipi.go.id) dated 15 February 2013.

[6] Edi Syahputra, Increased spatial abilities of students through the application of Realistic Mathematics learning. 2013, The horizon of education. Journal.uny.ac.id

[7] Abdul Muin, (2012). Identifying the Ability of Mathematical Reflective Thinking. Paper Submitted to KNM XVI. 3-4 July. Jatinangor

[8] Muh Taufiqurrohma 2012. Domino card media for learning mathematics in class VII. jakarta.

[9] Heksanti, M. 2012 (nd). the use of Domino-Quartet (Domtet) Card Media in Learning German Speaking Skills Students of Class XI Bahasa 1 SMA Negeri Tumpang. P. 7-9. 